Inga Głuszek

https://doi.org/10.26485/AAL/2021/67/3

\title{
BLACK-GLOSS POTTERY FOUND IN A RESIDENTIAL BUILDING IN NIKONION. RESEARCH SEASONS 2008-2011
}

\begin{abstract}
The paper concerns the discoveries of tableware made in the black-gloss technique, which were found in a living house uncovered in Nikonion during the excavations in 2008-2011. However, the following paper constitutes a detailed analysis of the discoveries directly related to the usability of the uncovered house. Among the discoveries of black-gloss pottery related to the house's floor levels the oldest can be dated to the end of the $4^{\text {th }}$ century BC, most of the discoveries are dated as far as the $3^{\text {rd }}$ century BC. Most of the finds present the products of Attic workshops, but there are three examples of vessels that come from other production centres
\end{abstract}

Key words: Greek colonies, Black Sea, black-glosss pottery

CERAMIKA CZARNOPOKOSTOWANA ZNALEZIONA W BUDYNKU MIESZKALNYM W NIKONION. SEZONY BADAWCZE 2008-2011

\begin{abstract}
ABSTRAKT Artykuł dotyczy grupy znalezisk ceramiki czarnopokostowanej, które pochodzą z domu odkrytego w Nikonion podczas wykopalisk w latach 2008-2011. W tekście przedstawiono szczegółową analizę zabytków bezpośrednio związanych z poziomem użytkowym domu. Wśród znalezisk znalazły się naczynia datowane na koniec IV wieku p.n.e., większość znalezisk odnosi się do III wiek p.n.e. Wśród zabytków przeważają naczynia reprezentujące produkty warsztatów attyckich. W prezentowanym materiale źródłowym znalazły się również trzy przykłady naczyń pochodzących z innych ośrodków produkcyjnych
\end{abstract}

Słowa kluczowe: kolonie greckie, Morze Czarne, ceramika czarnopokostowana

Introduction

The paper concerns the discoveries of tableware made in the black-gloss technique, which were found in a living house uncovered in Nikonion during the excavations in 2008-2011. ${ }^{1}$ The finds are in direct ling with the building's floor level, and their analysis brought data that complement the chronological interpretation of the complex. The author's

1 I would also like to express my deep gratitude to N.M. Sekerskaâ and S.B. Okhotnikov for the possibility of working with black gloss pottery findings from Nikonion from all excavations which had been performed at the site since 1955. I would also like to thank for all information I received about the archaeological context of that findings. Words of thankfulness should also go to professor M. Mielczarek, who had begun and steel continued archaeological recherche in northern Black Sea region, his support and encouragement were crucial for the Author in process of writing of that article. previous publications on ceramic finds from the research conducted in 2008-2011 concerned all discoveries of black-gloss pottery excavated during archaeological research. The study concerned the characteristics of all finds in terms of typology, chronology and quantity. ${ }^{2}$ However, the following paper constitutes a detailed analysis of the discoveries directly related to the usability of the uncovered house. It also contains an interpretation of finds in the context of where they have been found within the uncovered residential complex.

The history of excavations

The joint studies by the Archaeological Museum in Odessa and Nicolaus Copernicus University in Torun commenced in 1995. The scholarly

2 Głuszek 2015: 223-228; 2018. 
and on-merits supervisor of the Ukrainian-Polish project involving not only archaeological research, but also more general issues related to the Greek settlement of the north-west coast of the Black Sea, is prof. M. Mielczarek. Together with the Ukrainian team led by N.M. Sekerskaâ, ${ }^{3}$ the Polish expedition was carrying excavations in the western and south-western part of Nikonion within the years 1995-2006. ${ }^{4}$ The archaeological works done in the location where the residential complex was discovered were initiated in 2007. The author of this paper was responsible for archaeological works on-site done by the Ukrainian-Polish team within the years $2008-2011,{ }^{5}$ in 2012 the excavations works were led by Krzysztof Jarzęcki, PhD. The archaeological works on-site carried out by the Ukrainian-Polish team were suspended in 2012.

\section{The archaeological context}

The house from which the presented discoveries of black-gloss pottery originate is located in the north-west part of the site. During the excavation works, a residential building consisting of at least six rooms was uncovered. The northern part of the building has not been fully examined due to the suspension of excavation works. During four archaeological seasons, an area of 300 $\mathrm{m}^{2}$ (squares 1-12) was subject to examination. As a result of the excavation works, a vast residential building was uncovered, with registered dimensions of $10,50 \times 11,70 \mathrm{~m}$. It is the largest living house discovered in Nikonion so far. The part of the house unearthed during the excavations consists of six rooms (room 1-6), where four rooms were exposed in full (room 1, 2, 3, 5), as with two rooms $(4,6)$ their northern parts were not fully exposed (Fig. 1). ${ }^{6}$ In rooms 1, 3-5, the floor level was a floor made of compacted clay, in room 2 the uncovered floor was made of flat stones matching to each other, which do not bear traces of detailed processing, the northern part of the room was lined with small pebbles. The floor in room 6 consisted of large-sized stone slabs, lined over the entire surface of the room. In the south-west part of room 6 there was a pit, reinforced at the edges with a ring of circumferentially arranged stones.

3 Sekerskaâ 1989; 2001.

4 Mielczarek, Okhotnikov, Sekunda 1997; Mielczarek 2016.

5 Głuszek 2012: 497-500.

6 Głuszek 2012: 497-500; 2016: 20, fig. 2.
The walls of the rooms were made of stones, which had been treated only to the extent that gave them a shape that would allow for one stone to fit another. The stones are irregular, they are flat, and of varying sizes ranging from $25 \times 35$ to $65 \times 45 \mathrm{~cm}$. The wall between rooms 4 and 5 was constructed of sun-dried bricks. The bricks are approximately $68 \times 38 \times 25 \mathrm{~cm}$ in size. The uncovered walls of the house have been preserved up to a highest level of $60 \mathrm{~cm}$. At this particular stage of the research, it is not yet possible to determine the function of individual rooms, and to estimate the actual size of the building or definitively determine the number of rooms from which the complex consisted.

The black-gloss pottery finds

Among the discoveries of black-gloss pottery related to the house's floor levels the oldest can be dated to the end of the $4^{\text {th }}$ century BC, most of the discoveries are dated as far as the end of the first half of the $3^{\text {rd }}$ century BC. Most of the finds present the products of Attic workshops (cat. 1, 3-10, 12), but there are three examples of vessels that come from other production centres (cat. 2, 11, 13). Among the finds are everyday tableware such as echinus-shaped bowls (the type with an inward rim, known among Attic products from the classical period), bowls with an outward curved rim characteristic of the Hellenistic period, and examples of deep bowls. The second largest group are drinking vessels. This particular group involves the examples of vessels, which origins date back to the classical period, such as the Bolsal vessels; the others are the classic-shaped kantharos from the $3^{\text {rd }}$ century $\mathrm{BC}$ and one example of Hellenistic type kantharos. Other examples of black-gloss pottery are one plate with a rolled-up rim and a jug, probably oinochoe.

In room 1, a fragment of a kantharos was found (cat. 3, Fig. 2. 3), and it was dated to the last quarter of the $4^{\text {th }}$ - the third quarter of the $3^{\text {rd }}$ century BC A fragment is an example of a straight, plain rim type. The kantharos of this shape, although they appear at the end of the $4^{\text {th }}$ century $\mathrm{BC}$, become more popular in the $3^{\text {rd }}$ century $\mathrm{BC} .^{7}$ Vertical handles, rectangular in cross-section,

7 Sparkes, Talcott 1970: 122, fig. 7, no 707, 708; Rotroff 1997: 84-85, fig. 4, 1-12. The shape can be also compared with: Handberg, Petersen et al. 2010: 210, pl. 100, Da-80; Stolba, Rogov 2012: pl. 62. B11; Egorova 2009: ric. 1, 2. 


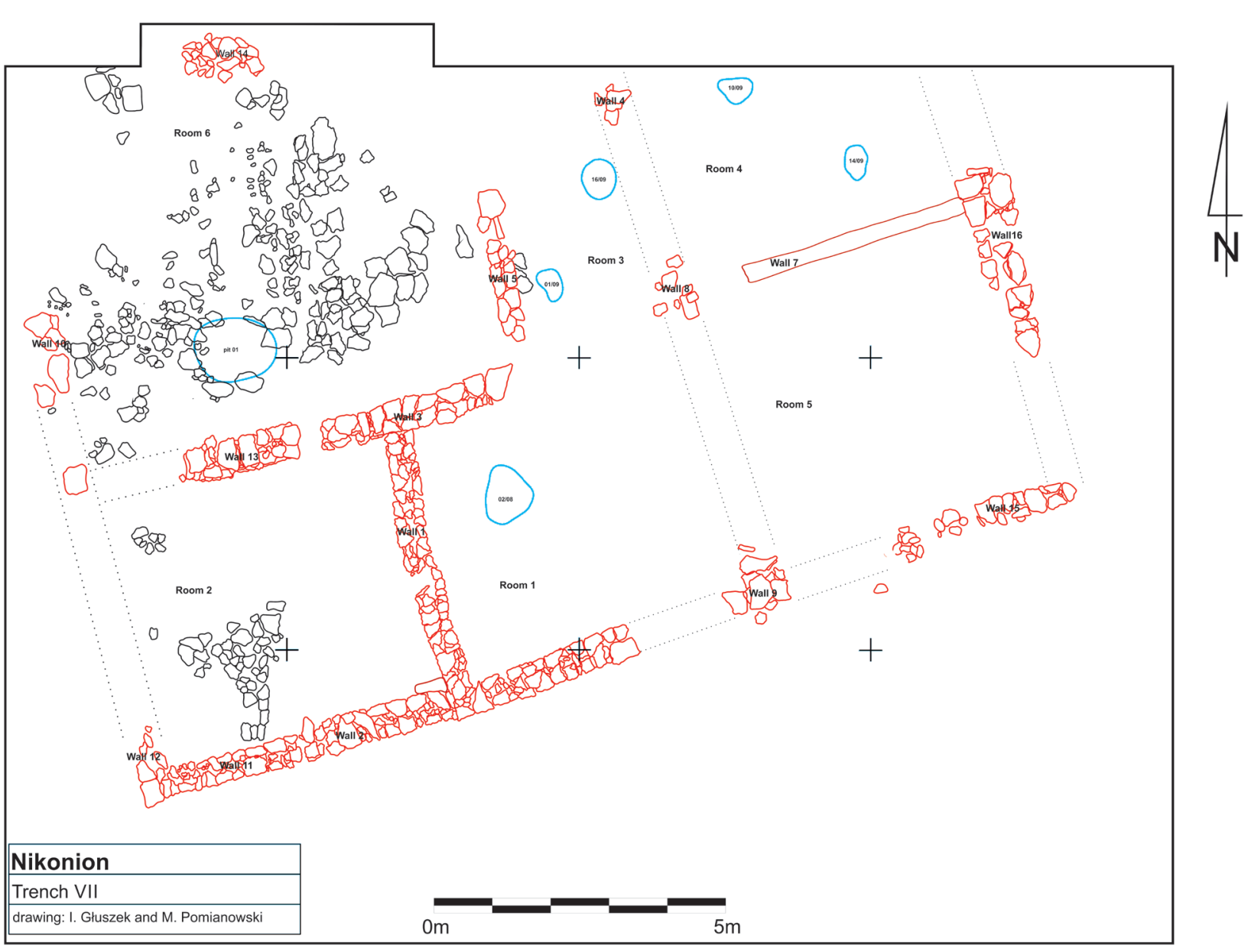

Fig. 1. The residential building found in Nikonion during archaeological excavations 2008-2011 (drawing by I. Głuszek and M. Pomianowski)

are provided with horizontal, conical spurs tapering at the apex, which are placed at the level of the rim or are slightly raised above the edge of the vessel. On the floor of the room there was also found a fragment of the upper part of the bowl with the incurving rim of echinus-shaped profile (cat. 5, Fig. 3. 1). The bowls of this type have been known among the Attic vessels since early as the $5^{\text {th }}$ century BC, they were especially popular in the fourth century $\mathrm{BC}^{8}$ The later examples are dated to the third century $\mathrm{BC}$ The vessel discovered in room 1 is characteristic of the Hellenistic type of the bowl-echinus bowl. ${ }^{9}$ These bowls are relatively thin-walled, the gloss is characterized by a weaker quality than in the case of Classical period items, the bowls are also devoid of a stamp ornament. There are also bowls covered with a gloss only on $1 / 2$ of their surface. The bowl of Nikonion adopts the profile line and proportions corresponding to

8 Sparkes, Talcott 1970: 131.

9 Rotroff 1997: 161. the finds from the Athenian Agora dated to the end of the $4^{\text {th }}$ - the beginning of the $3^{\text {rd }}$ century BC. ${ }^{10}$

On the floor of room 2, one fragment of a Bolsal, fragments of four bowls and a plate were discovered. The Bolsal's clay (cat. 2, Fig. 2. 2) is very specific one. It has vert dark orange to red colour with visible dark inclusions of un unrecognized geological character, limestone and quartz. The clay is fine fraction (not very fine fraction as it is observed in Athenian clay); what might be judged after macroscopic analyses, it is not hard burned. The features of the clay indicate that the vessel was produced in the different centre than Athens. The vessels from Olbia Pontica, characterised by the clay of comparable features but with gloss of lower quality, were recognised as a probable local or regional production ${ }^{11}$. The shape of the Nikonion

10 Rotroff 1997: 240, fig. 62, 982, 986; the other examples: Hermary, Panayotova et al. 2010: 130, 239, pl. 69f; Handberg, Petersen et al. 2010: 224, pl. 118, Dc282, 284.

11 Handberg, Petersen et al. 2010: 189. 
find represents a type that appears in the repertoire of Attic vessels in the second quarter of the fourth century BC. ${ }^{12}$ The shape of the rim slightly tilted outwards and the handles slightly rising upwards are characteristic features of specimens dating back to the end of the $4^{\text {th }}$ - beginning of $3^{\text {rd }}$ century BC..$^{13}$ Among the bowls, there is a fragment representing the echinus-shaped shallow, Classical type (cat. 6, Fig. 3. 6), the classic variant resembling the products manufactured in Attic workshops in the $5^{\text {th }}$ and $4^{\text {th }}$ century BC. Bowls of this type dated to the Hellenistic period are characterized by good workmanship and the use of a stamped ornament on a floor of the vessel. In the case of the Nikonion example, it is a palmette wreath surrounded by three rings of a rouletting ornament. Basing on the discoveries from the Athenian Agora, the bowl can be dated to the first quarter of the $3^{\text {rd }}$ century BC. ${ }^{14}$ A similar decorative scheme can be found on a plate dated to the last quarter of the fourth century BC. ${ }^{15}$ The next two fragments of bowl rims represent a type with outturned rim. It is one of the most widespread types of bowls produced in Athenian workshops. The production of bowls of this shape in Athens dates back to the fifth century $\mathrm{BC}$. These bowls were widespread during the Hellenistic period. The first of the examples from room 2 belongs to the Classic type with the edge strongly turned outwards, which in profile resembles a schematically presented bird's head (cat. 7, Fig. 3. 2). The production of bowls of the indicated shape and proportions dates back to the last quarter the $4^{\text {th }}$ century BC. ${ }^{16}$ The second fragment (cat. 8 , Fig. 3. 3) presents a variant dated to the end of the $4^{\text {th }}$ century $\mathrm{BC}$ with an equally characteristic shape of the rim, but larger sizes. ${ }^{17}$ Among the finds of black-gloss pottery from the floor level of room 2 there is also a fragment of the foot and the bottom part of the echinus-shape deep bowl (cat. 10, Fig. 3. 5). The bowls of this shape were known in the Athenian workshops in the $3^{\text {rd }}$ century BC.

12 Sparkes, Talcott 1970: 107-108, 275, fig. 6, no 558; see also: Chelbi 1992: nos. 340, 341, 348; Hermary, Panayotova et al. 2010: 203, pl. 94d.

13 Chelbi 1992: 56-57.

14 Rotroff 1997: 161, fig. 62, no 981, pl. 142, 145, 640.

15 Rotroff 1997: pl. 142, 145, no 640.

16 Rotroff 1997: 156-157, fig. 59, no 868; see also: Stolba, Rogov 2012: pl. 64, B103, 104; Vickers, Kakhidze 2004: 204, fig. 265; Egorova 2009: ric. 13, 169, 179.

17 Rotroff 1997: 156-157, fig. 59, no 869; the other examples of the shape: Handberg, Petersen et al. 2010: 226, pl. 121, Dc-309; Stolba, Rogov 2012: pl. 65, B113; Egorova 2009: ric. 14, 189, ric. 15, 211; ric. 40, Б 602.
The bowl found in Nikonion has a shape of the foot characteristic for examples dated to the first quarter of the $3^{\text {rd }}$ century BC. ${ }^{18}$ In room 2 , a fragment of a plate with a rolled rim was also discovered (cat. 12, Fig. 2. 5). The plates with a characteristic moulded, rolled rim began to be produced in Attic workshops at the beginning of the $4^{\text {th }}$ century BC. The shape of the preserved part of the vessel's edge and the reconstructed dimensions allow to date the fragment to the last quarter of the $3^{\text {rd }}$ century BC. ${ }^{19}$

In room 4, a fragment of a Bolsal and a fragment of a Hellenistic kantharos have been discovered. Bolsal began to be produced in Athenian workshops in the third quarter of the $5^{\text {th }}$ century $\mathrm{BC}$, the vessels dating back to this period are characterized by an undisturbed profile, which is slightly bent in the upper part. For vessels from the $4^{\text {th }}$ century $\mathrm{BC}$, the edge of the curled outwards while the wall just above is slightly concave creating a s-shaped line in the profile of the upper part of the vessel. The Nikonion example represents a transitional form with a vertical wall at the top and turned outwards the edge of the rim (cat. 1, Fig. 2. 1). The vessel can be dated to the early $4^{\text {th }}$ century BC..$^{20}$ The preserved fragment of the upper part of the Hellenistic kantharos depicts a type of vessel with vertical, straight wall (cat. 4, Fig. 2. 4). Hellenistic kantharos appear in the repertoire of Attic vessels in the mid of $3^{\text {rd }}$ century BC. The shape of vessels with straight walls, which were the first to appear in Attic workshops, derives from Beotian vessels dating back to the fifth century BC. The example from Nikonion presents a variant of large size with a straight wall, which can be dated to the first quarter of the $3^{\text {rd }}$ century BC..$^{21}$

Among the black-gloss vessels from the floor level of the room 5 is another example of the bowl with outturned rim (cat. 9, Fig. 3. 4). The characteristic shape of the edge indicates the classical variants of bowls dating back to the second half of $3^{\text {rd }}$ century BC. ${ }^{22}$

18 Rotroff 1997: 162-163, fig. 64, no 1029; compare with: Egorova 2009: ris. 21, 300.

19 Rotroff 1997: 142-145 fig. 46, 641; see also: Handberg, Petersen et al. 2010: 233, pl. 121, Da-389, 392, 394; Stolba, Rogov 2012: pl. 66, B147, 148; Egorova 2009: ris. 27, 440, 448.

20 Sparkes, Talcott 1970: 107-108, 275, pl. 6, no 557; other examples from the Black Sea territory: Vickers, Kakhidze 2004: 169, fig. 122, 237.

21 Rotroff 1997: 97-100, 260, fig. 13, no 172-173.

22 Rotroff 1997: 157, fig. 61, no 883, 888, 889; see also: Handberg, Petersen et al. 2010: 225, pl. 120, Dc-298, 299. 
In room 6, however, a fragment of a black-gloss jug (cat. 13) and a deep bowl (cat. 11) were found. A fragment of the bottom of the jug represents a vessel which technological features indicate that it might represents an Italian workshop. Analysis of the form allows to suggests that jug (oinochoe) represents the products of Italian workshops from the last quarter of the $4^{\text {th }}$ century $\mathrm{BC} .{ }^{23}$ Along with the jug, a fragment of bowl was discovered, which also does not originate from Athens. The fragment is heavily damaged, however, it can be assumed that it presents the foot and a fragment of the bottom of a deep bowl with a protruding edge, dated to the third quarter of the $3^{\text {rd }}$ century BC. ${ }^{24}$

Catalogue ${ }^{25}$

Bolsal

cat.: 1

Fig. 2. 1

Inv.: Nikonion/VII/09/213

Bibliography: Głuszek 2015, 223-228; 2018.

Context: room 4.

Dimensions and conditions: diam. of the rim: 16 $\mathrm{cm}$. The small part of the upper part with trace after hand attachment is preserved.

Technical features: clay: 5YR 7/6-6/6; gloss: black with dark blue shade, thick, semi-matte; inclusions: mica.

Description: the vessel with plain rim and a slightly arched wall in profile.

Classification and date: Athens, Bolsal, early $4^{\text {th }}$ c. BC.

Comments: Sparkes, Talcott 1970: 107-108, 275, p1. 6,557 . The finds of Bolsals are very common finds at Black Sea sites, among this finds there are also present examples of the type comparable in shape to the Nikonion find: Pichvnari: Vickers, Kakhidze 2004: 169, fig. 122, 237.

cat.: 2

Fig. 2.2

Inv.: Nikonion/VII/10/36

Bibliography: Głuszek 2015: 223-228; 2018.

Context: room 2

23 Morel 1981: 375, pl. 179, no 5623b 1; Pedroni 1990, 1990: 70, tav. 24, 112.

24 Rotroff 1997: 167, 348, pl. 79, 1092; see also: Egorova 2009: ric. 52, A800.

25 The catalogue is divided according to the forms of utensils: drinking vessels, bowls, plates, closed vessels-pitchers. The finds are listed according to provenance in each category: Athenian and other vessels, and chronologically.
Dimensions and conditions: diam. of the rim: 10-16 $\mathrm{cm}$. The small fragment of the rim and handle is preserved.

Technical features: clay: $2.5 \mathrm{YR} 5 / 8$; gloss: black with dark blue shade, thick, semi-matte; inclusions: limestone, quartz, dark inclusions of unrecognisable geological character. The fragment of the rim and handle is preserved.

Description: the rim has a round, plain edge, the handle is horizontal, oval in cross-section.

Classification and date: the non-Athenian workshop, Bolsal, the second quarter of the $3^{\text {rd }} \mathrm{c}$. BC.

Comments: the vessel from the non-Athenian workshop; the features of clay suggested the non-Athenian workshop, not excluding local/ regional production: Handberg, Petersen et al. 2010: 189. The shape is comparable with Sparkes, Talcott 1970: 107-108, 275, fig. 6, 558; the other examples dated to the end of the $4^{\text {th }}$ - beginning of $3^{\text {rd }}$ century BC compare with: Chelbi 1992: nos. 340, 341, 348. The Athenian examples are known from the other Black Sea sites like Apollonia Pontica: Hermary, Panayotova et al. 2010: 203, pl. 94d.

Kantharos

cat.: $3 \quad$ Fig. 2.3

Inv.: Nikonion/VII/08/50

Bibliography: Głuszek 2018.

Context: room 1.

Dimensions and conditions: diam.: $10 \mathrm{~cm}$. The small fragment of the rim and handle is preserved.

Technical features: clay: 2.5YR 6/4-5YR 6/6; gloss: black with bronze shade, thick, semi-matte.

Description: the vessel has vertical handles with long horizontal spurs, which is rectangular in section.

Classification and date: Athens, kantharos, plain rim, last quarter of the 4 th - third quarter of the $3^{\text {rd }}$ c. BC.

Comments: the fragment represents the kantharos with plain rim type, close to Sparkes, Talcott 1970: 122, fig. 7, 707, 708; Rotroff 1997: 84-85, fig. 4, 1-12. The example of kantharos with comparable shape and proportion of upper part of the vessel's wall are known from Olbia Pontica dated to the last quarter of the $4^{\text {th }}$ c. BC: Handberg, Petersen et al. 2010: 210, pl. 100, Da-80. The examples of drinking vessels of a comparable shape are also present among finds from the necropolis of Panskoye I: Stolba, Rogov 2012: pl. 62. B11; also compare with: Egorova 2009: ric. 1, 2. 
Hellenistic kantharos

cat.: 4

Fig. 2.4

Inv.: Nikonion/VII/09/163

Bibliography: Głuszek 2015; 2018.

Context: room 4.

Dimensions and conditions: diam. of the rim: $12 \mathrm{~cm}$. The small fragment of the rim and wall with traces of the handle attachment is preserved.

Technical features: clay: 5YR 4/7-6/6; gloss: black with dark bronze shade, thick, semi-matte; inclusions: limestone.

Description: the edge of the rim is round with a little flattened inner surface, the wall is straight; only a trace of the handle attachment is preserved what not allows for its reconstruction.

Classification and date:Athens, Hellenistic kantharos, straight wall, the first quarter of the $3^{\text {rd }} \mathrm{c} . \mathrm{BC}$.

Comments: Rotroff 1997: 97-100, 260, fig. 13, 172-173.

\section{Bowl}

cat.: $5 \quad$ Fig. 3. 1

Inv.: Nikonion/VII/08/36

Bibliography: Głuszek 2015; 2018.

Context: room 1.

Dimensions and conditions: diam.: 11,6 cm, h.: 2 $\mathrm{cm}$. The fragment of the rim with the small part of the wall is preserved.

Technical features: clay: 5YR 6/4; gloss: black with bronze shade, a little dilute, semi-matte.

Description: the vessel has thickened lip, flattened edge of the rim; the wall bends clearly below the edge.

Classification and date: Athens, bowl, echinus-shape, Classical type, shallow, the third quarter of $4^{\text {th }} \mathrm{c} . \mathrm{BC}-3^{\text {rd }} \mathrm{c} . \mathrm{BC}$.

Comments: the shape of the lip corresponds with: Rotroff 1997: fig. 62, 982, 986. The comparable in shape vessels are known from Athenian finds of Apollonia Pontica: Hermary, Panayotova et al. 2010: 130, 239, pl. 69f, dated to the last quarter of the $4^{\text {th }} \mathrm{c}$. BC. The examples of late bowls of this shape dated to the $3^{\text {rd }} \mathrm{c}$. $\mathrm{BC}$ are known from Olbia Pontica excavations: Handberg, Petersen et al. 2010: 224, pl. 118, Dc-282, 284.

cat.: $6 \quad$ Fig. 3.6

Inv.: Nikonion/VII/10/78

Bibliography: Głuszek 2015; 2018.

Context: room 2

Dimensions and conditions: diam. of the foot: $10 \mathrm{~cm}$; the fragment is reconstructed from four sherds.

Technical features: 5YR 6/6-6/8; gloss: black with dark bronze, thick, a little dilute, matte.
Description: the one half of the bottom and floor of the bowl; the vessel has thick walls.

Decoration: at the inner surface of the floor there is a partly preserved decoration consist of the wreath of palmettes and sequence of three circles of rouletting.

Classification and date: Athens, bowl, echinus-shape, Classical type, shallow, the first quarter of $3^{\text {rd }} \mathrm{c} . \mathrm{BC}$.

Comments: the shape is close to: Rotroff 1997: 161, fig. 62, 981; decoration is close to: Rotroff 1997: pl. 142, 145, 640.

\section{cat.: $7 \quad$ Fig. 3. 2}

Inv.: Nikonion/VII/10/74

Bibliography: Głuszek 2015; 2018.

Context: room 2.

Dimensions and conditions: diam. of the rim: $15 \mathrm{~cm}$; a small part of the rim, there are scratches and gloss chips at the edge of the outer surface.

Technical features: clay: 5YR 6/6; gloss: black with metallic olive shade, thick, metallic shine

Description: the rim is turned outside, flattened rim, the edge is rounded.

Classification and date: Athens, bowl, outturned rim, Classical type, the last quarter of the $4^{\text {th }} \mathrm{c}$. BC.

Comments: Rotroff 1997: 156-157, fig. 59, 868. The bowls of that type are represented among finds from the necropolis of Panskoye I: Stolba, Rogov 2012: pl. 64, B103, 104 and Pichvnari: Vickers, Kakhidze 2004: 204, fig. 265. Compare also with: Egorova 2009: ric. 13, 169, 179.

cat.: $8 \quad$ Fig. 3.3

Inv.: Nikonion/VII/10/69

Bibliography: Głuszek 2015; 2018.

Context: room 2.

Dimensions and conditions: diam. of the rim $17 \mathrm{~cm}$; lots of scratches of the inner and outer surface

Technical features: clay: 7.5YR 6/4-5YR 5/6; gloss: black with grayish brown shade, a little dilute, matte.

Description: the rim is turned outside, the edge is thickened and rounded, the wall below is straight and arched inside at the edge of the sherd.

Classification and date: Athens, bowl, outturned rim, Classical type, the last quarter of the $4^{\text {th }} \mathrm{c}$. BC.

Comments: the shape and proportions are close to: Rotroff 1997: fig. 59, 869. The comparable examples from the first decade of the $3^{\text {rd }} \mathrm{c}$. BC are known from Olbia Pontica: Handberg, Petersen et al. 2010: 226, pl. 121, Dc-309; and from the necropolis of Panskoye I: Stolba, Rogov 2012: pl. 65 , B113. Compare also with: Egorova 2009: ric. 14,189 , ric. 15,211 ; ric. 40 , Б 602 . 
cat.: $9 \quad$ Fig. 3.4

Inv.: Nikonion/VII/11/135

Bibliography: Głuszek 2015; 2018.

Context: room 5 .

Dimensions and conditions: diam. of the rim: 16 $\mathrm{cm}$. The small part of the upper part of the vessel is preserved; the gloss is chipped at the outer edge of the sherd.

Technical features: clay: 7.5YR 7/4-5YR 7/3; gloss: black with very dark grey shade, semi-dilute, matte.

Description: the edge of the vessel is thickened, round at the top, turned outside.

Classification and date: Athens, bowl, outturned rim, Classical type, the second half of $3^{\text {rd }} \mathrm{c} . \mathrm{BC}$.

Comments: Rotroff 1997: 157, fig. 61, 883, 888, 889. The comparable finds of bowls in this shape are known from Olbia: Handberg, Petersen et al. 2010: 225, pl. 120, Dc-298, 299 dated to the $3^{\text {rd }} \mathrm{c}$. BC.

cat.: 10

Fig. 3.5

Inv.: Nikonion/VII/10/42

Bibliography: Głuszek 2015; 2018.

Context: room 2.

Dimensions and conditions: diam. of the foot: $6 \mathrm{~cm}$; the fragment of the foot and the bottom wall of the vessel, the foot is highly damaged.

Technical features: clay: 5YR 6/4; gloss: black with brown shade, thick, matte.

Description: the flat resting surface, straight inner surface of the foot, the outer surface is arched.

Classification and date: Athens, bowl, echinus-shape, deep, the first quarter of the $3^{\text {rd }} \mathrm{c}$. BC.

Comments: Rotroff 1997: 162-163, fig. 64, 1029; compare also with: Egorova 2009: ris. 21, 300.

cat.: 11

Inv.: Nikonion/VII/10/108

Bibliography: Głuszek 2018.

Context: room 6 .

Dimensions and conditions: diam. of the foot: 10 $\mathrm{cm}$. The fragment of the foot is preserved with a highly damaged inner and outer surface.

Technical features: clay: 5YR 6/6-6/8; gloss: very dark bronze with olive shade, thick, metallic shine.

Description: the foot is moulded and has flat resting surface.

Classification and date: non-Athenian workshop, deep bowl, the third quarter of the $3^{\text {rd }} \mathrm{c}$. BC.

Comments: Rotroff 1997: 167, 348, pl. 79, 1092. Compare also with: Egorova 2009: ric. 52, A800.
Plate

$$
\text { cat.: } 12 \quad \text { Fig. } 2.5
$$

Inv.: Nikonion/VII/10/43

Bibliography: Głuszek 2015; 2018.

Context: room 2.

Dimensions and conditions: diam. of the rim: 25 $\mathrm{cm}$, the small fragment of the plate edge is preserved. There is a lot of scratches at the outer and inner space of the sherd.

Technical features: clay: 5YR 6/6-5/6; gloss: black with dark brown shade, thick, semi-matte.

Description: the edge is thickened, turned outside, rounded, the line of the profile below the edge is moulded.

Classification and date: Athens, plate, rolled rim, the last quarter of the $3^{\text {rd }} \mathrm{c}$. BC.

Comments: the edge of the plate is close to: Rotroff 1997: 144, fig. 46, 641. The examples of rolled rim plates are also known from Olbia Pontica: Handberg, Petersen et al. 2010: 233, pl. 121, Da-389, 392, 394; also from the necropolis of Panskoye I: Stolba, Rogov 2012: pl. 66, B147, 148. Compare also with: Egorova 2009: ris. 27, $440,448$.

Jug

cat.: 13

Inv.: Nikonion/VII/10/107

Bibliography: Głuszek 2018.

Context: room 6.

Dimensions and conditions: diam. of the foot: 6,5 $\mathrm{cm}$. The half of the foot is preserved with a part of the wall. The underside is damaged.

Technical features: clay: 5YR 6/3-7.5YR 6/3; gloss: black with grey shade, semi-dull, matte; inclusions: mica, limestone, quartz.

Description: The foot of the vessel is bevelled outside, with a slightly concave wall of the inner side of the foot, the resting surface is flat.

Classification and date: the non-Athenian workshop, jug, $4^{\text {th }}$ c. BC.

Comments: Morel 1981: 375, pl. 179, 5623b 1; Pedroni 1990: 70, tav. 24, 112. 

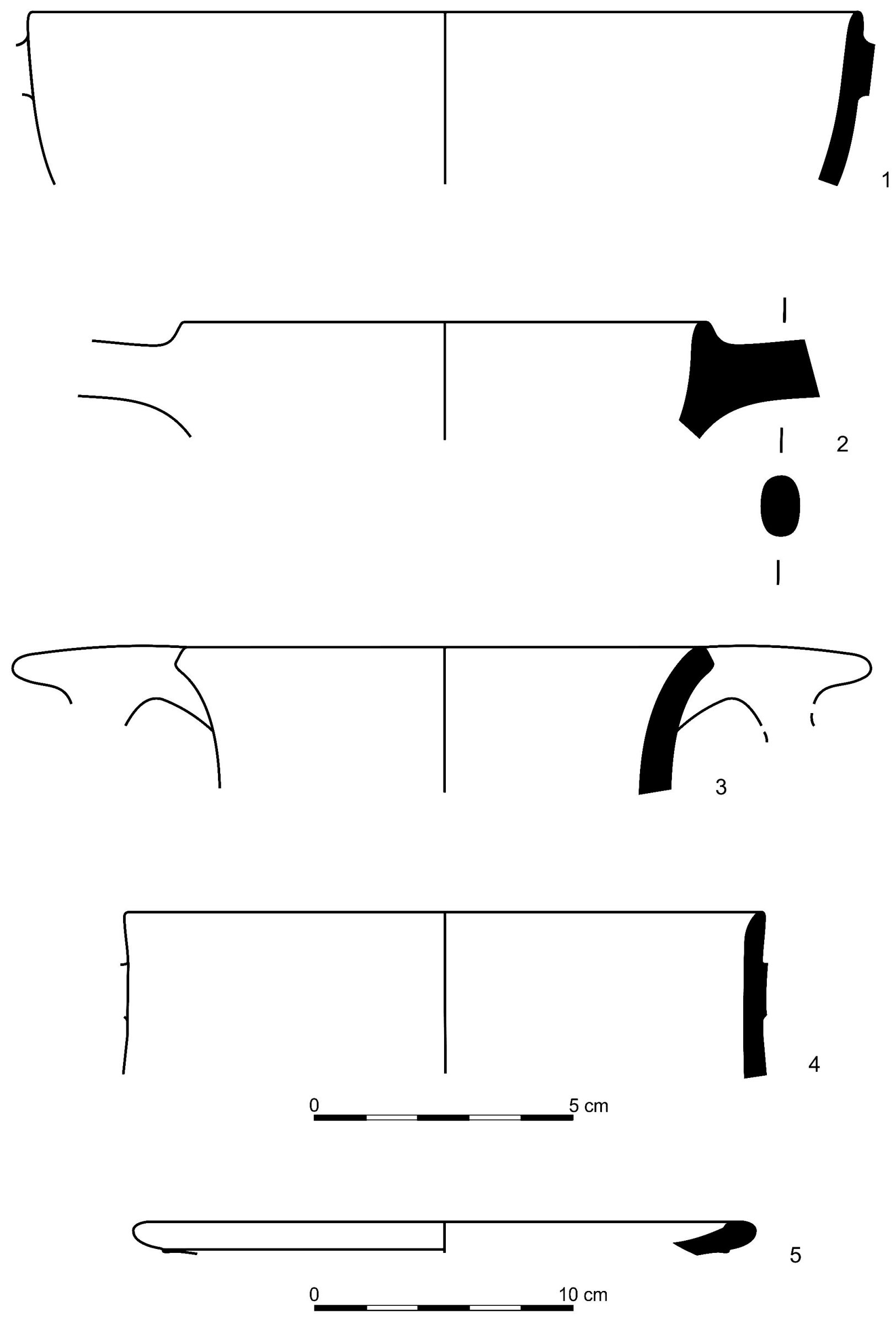

Fig. 2. Black-gloss pottery found at the floor level of house in Nikonion. Excavations 2008-2011 (drawing by I. Głuszek) 

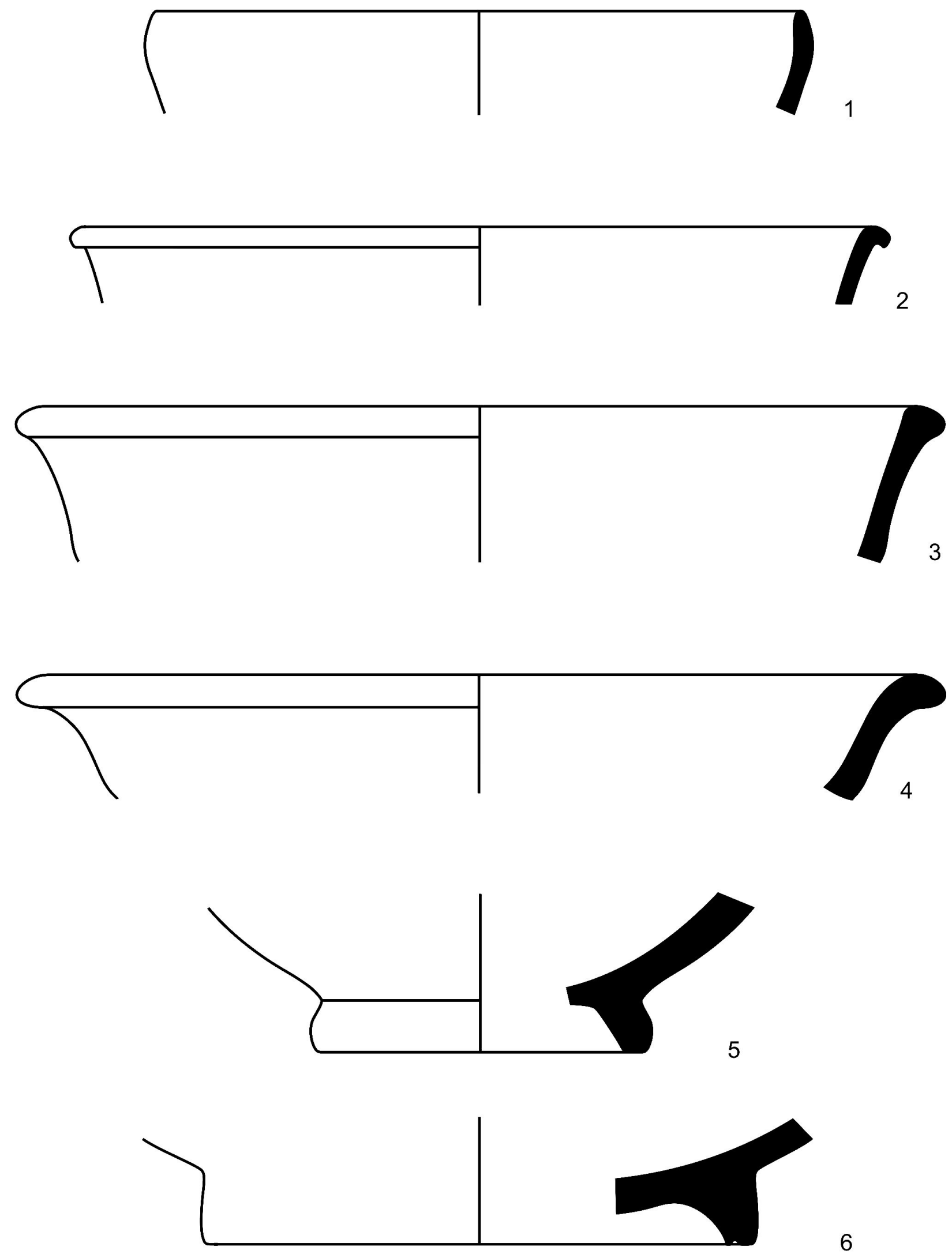

Fig. 3. Black-gloss pottery found at the floor level of house in Nikonion. Excavations 2008-2011 (drawing by I. Głuszek) 


\section{Bibliography}

Chelbi F. 1992. Ceramique a vernis noir de Carthage, Tunis: Institut national d'archéologie et d'art.

Egorova T.E. 2009. Chernolakovaâ keramika IV-II vv. do n. e. s pamâtnikov Severo-Zapadnogo Kryma. Moskva.

Głuszek, I. 2012. The development of architecture in Nikonion in $4^{\text {th }}$ century BC, in: V. N. Zin'ko (ed.), Bosporan readings XII. The Cimmerian Bosporus and barbarian world in the period of Antiquity and the Middle Ages: problems of urbanization, Kerch, 497-500.

Głuszek I. 2016. The private letter discovered in Nikonion. Acta Archaeologica Lodziensia, nr 62, s. 19-30.

Głuszek I. 2015. Chernolakovaâ keramika iz raskopok Nikoniâ 2008-2011 gg. Materialy po arheologii Severnogo Pričernomorâ. vyp. 13, s. 223-228.

Głuszek I. 2018. Studia nad ceramiką czarnopokostowaną z wykopalisk w Nikonion. Dystrybucja naczyń czarnopokostowanych w ośrodkach greckich północno-zachodniego wybrzeża Morza Czarnego, Toruń: Wydawnictwo Uniwersytetu Mikołaja Kopernika w Toruniu.

Handberg S., Petersen J.H., with contribution Bilde P.G., Bjerg L.M.H., Samojlova T.L. 2010. D Glossed pottery. In N.A. Lejpunskaja, P. Guldager Bilde, J. Munk Højte, V.V. Krapivina, S.D. Kryzhitskiy (eds.), The Lower City of Olbia (Sector NGS) in the $6^{\text {th }}$ Century BC to the $4^{\text {th }}$ Century AD, Vols. 1-2, Aarhus, 186-260.

Hermary A., Panayotova K., Baralis A., Damyanov M., Riapov A. 2010. Apollonia du Pont (Sozopol) la necropole dr Kalafata (V-III s. av. J.-C.). Fouilles franco-bulgares (2002-2004), Paris.

Mielczarek M. 2016. Houses Dug into the Ground in Ancient Nikonion in the Lower Dniester Region. In E. Maik (ed) Fasciculi Archaeologiae Historicae. From Studies in the Culture of Medieval Europe, XXIX, 83-92.
Mielczarek M., Okhotnikov S.B. and Sekunda N.V. (eds) 1997. Nikonion. An ancient city on the Lower Dniester. Torun.

Morel J.P. 1981. Céramique campanienne: les formes. Rome.

Pedroni L. 1990. Ceramica a vernice nera da Cales, Liguori.

Rotroff S.I. 1997. Hellenistic Pottery: Athenian and Imported Wheelmade Table Ware and Related Material. Athenian Agora, vol. 29. Princeton, N.J.: American School of Classical Studies at Athens.

Sekerskaâ N.M. 1989. Antichnye Nikoniy i evo okruga. Kiev.

Sekerskaâ N.M. 2001. Nikonij. In Antichnye pamâtniki Sever-Zapadnogo Pričernomorâ. 115-138. Kiev.

Sparkes B.A., Talcott L. 1970. Black and Plain Pottery of the $6^{\text {th }}, 5^{\text {th }}$, and $4^{\text {th }}$ Centuries BC. The Athenian Agora 12. Princeton.

Stolba V.F., Rogov E. 2012 Panskoye I. Volume 2: The Necropolis. Aarhus University Press.

Vickers M., Kakhidze A. 2004. Pichvnari. Results of Excavations conducted by the Joint British-Georgian Pichvnari Expedition. Volume I. Pichvnari 1998-2002. Oxford. 